\title{
圈
}

\section{Editorial Volume 9, Issue 2}

\author{
Monir Mir ${ }^{1}$
}

There are five excellent studies which are published in this issue of Australasian Accounting, Banking and Finance Journal (AABFJ). As summarised below, out of these five studies, four of the studies have investigated and explored various accounting, finance and accountability issues of emerging and developing economies. Although more needs to be done, it is encouraging to observe that researchers from developing and emerging economies have been making progress in disseminating their research findings to the interested global communities.

Mazzola and Gerace (2015) investigate the sensitivities of Capital Asset Pricing Model (CAPM) in predicting returns when the risk-return assumptions of CAPM are changed. Through constructing two theoretical portfolios based on the securities in the Australian securities market, they find that when the CAPM's assumptions are extended through continuously rebalancing portfolios then the portfolio provides superior returns compared to a portfolio not continuously rebalanced. There are numerous studies that have contributed in either modifying and/or extending the simplistic CAPM assumptions since its introduction by William Sharpe in 1964 (though many scholars of portfolio theory also claim that it was Jack Treynor who first hinted about CAPM in 1962). All these studies have enriched the theoretical and practical contributions of CAPM and investors and fund managers were immensely benefitted. Mazzola's and Gerace's (2015) study is one of such extensions expected to be highly appreciated not only by the participants of Australian securities market but also participants of securities markets globally.

While Mazzola and Gerace (2015) investigate the effects changing the risk-return assumptions of CAPM on portfolio returns, Abdallah and Hilu (2015) investigate the factors that influence the risk attitudes of investors. They sampled investors who traded in the securities market in the United Arab Emirates (UAE) and have identified a number of factors that can be used to predict investors' risk attitudes. There are not too many studies that have

\footnotetext{
${ }^{1}$ University of Canberra. Monir.Mir@canberra.edu.au
} 
investigated the behaviours of stock market participants in the emerging and developing economies. The finding of Abdallah's and Hilu's (2015) study on the UAE stock exchange is a significant contribution for understanding the risk-return and the market efficiency aspects of developing and emerging economies.

The paper of Kusumawardhani et al (2015)., and Passant et al. (2015), bring up the age old debates of the pros and cons of the government interventions in governmental macroeconomic policy making. The debate has never stopped since the introduction of the metaphor of 'invisible hand' by Adam Smith that is, the arguments against protectionism. Based on case studies in the Indonesian context, Kusumawardhani et al. (2015), propose that the protection of micro, small and medium enterprises are required for the economic developments of the developing countries like Indonesia. On the other hand Passant et al. (2015), find that unplanned and non-visionary protections of mining resources contribute to less job creation and reduced productivity in Indonesia. These two studies show us that neither extreme protectionism nor extreme liberalisation will work in the economic development of developing economies and also point out that visionary and planned state protections will bring the intended benefits of protectionism.

International financial institutions have categorised the Indian economy with three other fast emerging economies (Brazil, Russia and China) which is famously known as 'BRICOnomies'. They predict that this century may well see economic power shifting to BRIC nations as they have laid the ground work for decades of new economic growth. However, nobody will ignore the fact that the economic growth of BRIC economies comes with increased responsibility for sustainable developments in these countries and their impacts globally. Then there come the debates on what should be the roles of the corporate sectors in these countries in the trade-off amongst their social, environmental and financial performances. Empirical evidence has already been accumulated internationally to answer the question of whether it "pays to be green" and the findings of these studies are inconclusive. That is, some studies have claimed that it pays to be green and at the same time, other studies have observed that it does not pay to be green. Bhattacharyya (2015) in his paper argues that India, although enjoying a high economic growth rate similar to other BRIC and emerging economies, is not doing enough in terms of its responsibility with respect to sustainable development. Like many other emerging economies, India is also highly vocal against adopting regulatory measures to contribute to sustainable development citing the negative financial impacts of such measures in its corporate and business sectors. However, Bhattacharyya (2015) provides evidence that the Indian corporate sector will welcome mandatory corporate social responsibility reporting which indicates that Indian regulators should not be shying away from implementing stringent regulations promoting the sustainable development of India. 


\section{References}

Abdallah, Salam and Hilu, Khalil, (2015) Exploring Determinants to Explain Aspects of Individual Investors' Financial Behaviour, Australasian Accounting, Business and Finance Journal, 9(2), 2015, 4-22.

Available at:http://ro.uow.edu.au/aabfj/vol9/iss2/2 DOI http://dx.doi.org/10.14453/aabfj.v9i2.2

Bhattacharyya, Asit, (2015)Corporate Social and Environmental Responsibility in an Emerging Economy: Through the Lens of Legitimacy Theory, Australasian Accounting, Business and Finance Journal, 9(2), 2015, 79-92. Available at:http://ro.uow.edu.au/aabfj/vol9/iss2/6

DOI http://dx.doi.org/10.14453/aabfj.v9i2.6

Kusumawardhani, Dhian; Rahayu, Amy Y.; and Maksum, Irfan Ridwan, (2015) The Role of Government in MSMEs:The Empowerment of MSMEs During the Free Trade Era in Indonesia, Australasian Accounting, Business and Finance Journal, 9(2), 2015, 23-42. Available at:http://ro.uow.edu.au/aabfj/vol9/iss2/3 DOI http://dx.doi.org/10.14453/aabfj.v9i2.3

Mazzola, Paul and Gerace, Dionigi, (2015) A Comparison Between a Dynamic and Static Approach to Asset Management Using CAPM Models on the Australian Securities Market, Australasian Accounting, Business and Finance Journal, 9(2), 2015, 43-58. Available at:http://ro.uow.edu.au/aabfj/vol9/iss2/4 DOI http://dx.doi.org/10.14453/aabfj.v9i2.4

Passant, John; McLaren, John; Silaen, Parulian; and Wickramasinghe, Ananda, (2015) The Asian Development Model and Mining Reforms in Indonesia, Australasian Accounting, Business and Finance Journal, 9(2), 2015, 59-78. Available at:http://ro.uow.edu.au/aabfj/vol9/iss2/5 DOI http://dx.doi.org/10.14453/aabfj.v9i2.5 